\title{
'The issue of the Mediterranean and the colonies has now moved to the forefront of cultural life': curating museums and curating the nation in Fascist Italy's colonies
}

\author{
Beatrice Falcucci* \\ University of Florence, Italy \\ (Received 6 January 2020; final version accepted 19 August 2020)
}

\begin{abstract}
The Fascist model of exhibiting power and placing it in museum settings had its origins in the Liberal exhibitions of the late nineteenth century, and in the first exhibitions devoted to the Risorgimento. However, the regime's museum initiatives were numerous, innovative and varied, and many of them have not yet been adequately investigated; those launched in Italy's colonies, in particular, remain largely unexplored. This article highlights the surprisingly extensive network of museums and temporary exhibitions that Fascism initiated in Italian possessions abroad, involving prominent figures from the regime and contemporary culture, and shows how science, culture and nation-building (in both the colonies and the mother country, and between them) were interwoven in the Fascist museological project for the colonies.
\end{abstract}

Keywords: museums; Italian colonies; Fascism; Libya; Italian East Africa.

\section{Introduction}

This article belongs within a broader range of investigations into Italy's propaganda endeavours in the colonial sphere, especially under Fascism. Writing in the mid-1930s, the geologist and explorer Ardito Desio stated that 'the issue of the Mediterranean and the colonies has now moved to the forefront of cultural life'. ${ }^{1}$ The policies on museums and exhibitions implemented in Italy's colonies were an important aspect of the attempt to create what Adolfo Mignemi (1984) has called a 'coordinated image for empire': a coherent and credible imaginary that would provide backing for the Italian people's imperialist aspirations, whether real or supposed, and, especially, would buttress support for the regime (Deplano 2015). Fascism's construction of myths, rituals, images and symbols in every sphere of operations has been thoroughly investigated (by, for example, Victoria De Grazia [1981] and Simonetta Falasca Zamponi [2003]); in the colonial context, there has already been ample research into its prolific production of textbooks suitable for educating the Empire's new pioneers (Gabrielli 2013; Labanca 2003), into film and documentary production in an imperial setting (Mancosu 2014), into literature (Ricci 2005), and into the activity of cultural institutes in support of colonialism (Ghezzi 2003). As I will show, Fascism's approach was also reflected, applied and fulfilled in its museum policy.

The relationship between Italian colonialism and museums was first addressed by Nicola Labanca in his edited collection L'Africa in vetrina (1992); subsequently, Francesco Surdich (2000) set out key lines of enquiry in a conference presentation. The intention of both these projects

\footnotetext{
*Email: beatrice.falcucci@unifi.it
}

(C) The Author(s), 2020. Published by Cambridge University Press on behalf of the Association for the Study of Modern Italy. This is an Open Access article, distributed under the terms of the Creative Commons Attribution-NonCommercial-NoDerivatives licence (http:// creativecommons.org/licenses/by-nc-nd/4.0/), which permits non-commercial re-use, distribution, and reproduction in any medium, provided the original work is unaltered and is properly cited. The written permission of Cambridge University Press must be obtained for commercial re-use or in order to create a derivative work. 
was to stimulate discussion of the ways in which objects and other findings from the country's colonies were exhibited in various types of museum in the Italian peninsula. More recently, writers have focused on the exhibitions of colonial art staged both in Italy and abroad (Tomasella 2017). The only museum initiatives in the colonies considered to date have been those connected to archaeology, although these have been examined more in the context of the history of this discipline under Fascism and not so much as 'colonial' phenomena (Munzi 2001).

This article indicates some starting points for more comprehensive research into the strategies, action and outcomes of museology in the Italian colonies, under both Liberal Italy and, more especially, the Fascist regime.

\section{Museums in Italian Libya: celebration of Roman archaeology and promotion of natural sciences}

In Italy itself, archaeology was employed - not just by Fascism, as is usually thought - to encourage practices and behaviour that would make Italians the worthy heirs of ancient Rome: wellknown examples include the archaeological exhibition at the Baths of Diocletian in 1911 and the bimillennial celebration of Augustus' birth in 1937. In the colonies, however, it was used with subjugated populations to confirm Italy's legitimate ownership of these territories: Italians were presented as heirs to the peninsula's ancient inhabitants, who had left so many traces of their glorious past in distant lands (Di Lauro 1938, 25-30; Cagnetta 1991-1992). This message had important cultural resonances, given that 'romanità', as Joshua Arthurs (2015) observes, was a central pillar and consistent feature of the regime's propaganda, right from the early days of the Fascist movement until its collapse in 1943.

The best-known 'colonial' museum of the Liberal era was undoubtedly the Museo Archeologico delle Sporadi, opened in 1916 in the large Hospital of the Knights of Rhodes. ${ }^{2}$ In both its quality of design and number of exhibits, this surpassed the small Libyan museums that had been hastily set up in Khoms (1913), Cyrene (1914) and Benghazi (1914) by Colonel De Albertis and other unknown army officers without archaeological qualifications. These exhibited the fragments and ruins randomly revealed as the army proceeded with the country's conquest, and were little more than storehouses (Munzi 2016). It was only in 1919 that Libya's first real archaeological museum was set up, inside the Red Castle in Tripoli. ${ }^{3}$ First envisaged five years earlier, it finally opened with a grand ceremony on 11 May, thanks to the endeavours of the archaeologist Salvatore Aurigemma (Aurigemma 1923, 191-220). Its temporary base was the castle guardroom from the Ottoman era, which provided a somewhat inadequate setting for one of the richest collections in Mediterranean Africa at that time (Bartoccini 1926, 566). Located within a single large room, the museum was arranged in four sections: one for Roman sculpture, which included the goddess Roma, one of the museum's most important exhibits, amongst about fifty statues; one for mosaics, especially the floor from the Dar Buk Ammera villa in Zliten, including the 'four seasons' tableau; one for grave goods and coinage; and one for the Islamic period. ${ }^{4}$ However, it had a very provisional character, in view of the mismatch between the limited space available and the aspiration to exhibit most of the items that they had been finding, and were still to find, from the whole of Libya.

In 1923 Renato Bartoccini was appointed director, a post he held until 1928. His arrival marked a surge in acquisitions by the museum, including new collections from Sabratha and Pisida (Bartoccini 1923, 7); he was not in favour of local museums, believing it important to have a single central institution. ${ }^{5}$ Under his aegis, the museum expanded in size and its organisation adopted an ideological perspective, in the attempt to offer the public a nationalistic celebration of the ancient 
world based on the dyad of 'romanità' and 'italianità'. This approach can be detected in the museum guide that Bartoccini produced, which dwelt on the discovery of 'a remarkable number' of Roman villas 'all along the Tripolitanian coast' and on the 'traces of Christian life'; by contrast, he emphasised the lack of 'evidence of the Muslim domination', an absence not matched elsewhere in northern Africa, which in his view must have resulted from 'the intellectual and cultural poverty' of the invaders compared to their Roman predecessors (1923, 17, 35, 42). Islamic archaeology and art were thus belittled; Bartoccini stated that the Muslims, 'while bitterly opposed to all memories of the idolaters (both pagan and Christian), were unable, however, to have these obliterated by other works that they themselves created' (42). In the area near the museum exit, moreover, the director organised a photographic display featuring Tripolitania's main classical monuments, hidden by the sand for centuries and only recently revealed by Italian excavations, which he interpreted as 'a solemn lesson for our people, the heirs over here of Rome' (56); the photographs were intended to impress the visitors, both Libyan and Italian, and encourage them to draw the appropriate conclusions for the present from the past.

This type of project, with cultural as well as museological aims, evidently needed more than an inferior building with limited space. Bartoccini therefore started to look for a larger and grander venue. However, it was only under his successor Giacomo Guidi, and with relocation of the governor of Libya's headquarters from the Red Castle to Shar al-Shatt (as required by the new incumbent Pietro Badoglio), that the museum found a new home, when the ample spaces of the Bastion of St George, restored in the early 1920s along with the rest of the Red Castle by the architect Armando Brasini, were handed over. ${ }^{6}$

The new Museo Archeologico was formally opened by Badoglio on 15 June 1930, in the presence of all Tripolitania's dignitaries. In Guidi's museum design the dominant theme remained the primacy of romanità, although there was also an attempt to emphasise the importance of Christian influences: so much so that there was a plan to house a Christian Museum in the adjacent former mosque. ${ }^{7}$ The theme of the exhibition layout was the recurrence of the past within the present, which came to a climax with an impressive statue of the goddess Roma; the return of Christian civilisation, on the other hand, was represented by a small fountain believed to have been brought to Tripoli by the Knights of Malta (Musso 2013, 21). Another interpretative key for navigating the museum was the harmony between colonised and colonisers; the idea was to illustrate the good relations between the Roman Empire's provinces and the mother country, presenting the colonised of the Roman era as submissive and loyal and implying that Libyans should behave in the same way. One display featured the cast of a Neo-Punic inscription from Leptis Magna that translated the titles of Augustus, recognising him as emperor and therefore indicating the reverence of the indigenous population towards Rome; next to this was a bust of the goddess Concordia found in Sabratha (Musso 2013, 21). The final interpretative thread related to agricultural prosperity, which the new colonists were encouraged to match (Falcucci 2019); this was particularly emphasised in the section dedicated to mosaics, which celebrated the earth's fertility in scenes of agricultural labour and compositions featuring abundant fruit and vegetables, and also resonated with the 'Battle for Wheat' and projects for comprehensive land reclamation undertaken by the Fascist regime in Italy (Sindacato Nazionale fascista tecnici agricoli 1937; Arthurs 2015).

A key intention of the colony's approach to its museums was to promote their accessibility to all, with tourists (Labanca 2000) and Italian colonists, but not really scholars, especially in mind: archaeological fragments, even if valuable or scientifically important, were therefore not publicly exhibited and were kept in separate workshops for experts in the field. The next governor, Italo Balbo, was particularly responsible for a boom period of tourism in Libya, and left his personal and distinctive mark on the museum; he always had one eye on the tastes and needs of the tourist, 
whether a wealthy foreigner interested in archaeology or an Italian making a sea trip to Libya, perhaps on the favourable terms offered by the Opera Nazionale del Dopolavoro (OND: Fascism's federation for leisure pursuits) (McLaren 2006; Capresi 2007). When Balbo arrived in Libya in January 1934, he immediately wanted to move the governor's offices back to the Red Castle, a symbol of power from which 'directives for government of the region had been issued for 20 centuries' (Guidi 1935, 22). However, he ordered that the museum should stay where it was, and should even be enhanced by displaying further finds. The offices of Balbo and his officials were therefore to be set up in the simplest way possible, leaving the halls full of the museum's sculptures and mosaics, with free entry for the public on Sundays (23); anyone who had an appointment with the governor would thus be 'naturally led to consider Italy's rule of Libya as a beneficial return of Rome, whose colonising endeavours are demonstrated by epigraphs and marvellous sculptures' (26). The manipulative and partisan use of archaeological heritage is especially obvious here; that aside, however, it should be noted that a unique model of museum presentation was on show, with the museum and offices overlapping:

While archaeologists, historians and art critics from every civilised country were meeting in Madrid in the autumn of 1934 to discuss issues relating to museum organisation, [we had] already actually put in place an example of a new museum, no longer aimed at just a scholarly circle but more broadly conceived. The marvellous classical works of art ... kept in the Bastion of St George, in the same rooms that are used for rule of the great Libyan possession, were intended to serve science, art and life alike. In the same way, traces of the ancient world were collected in government buildings of the Risorgimento

... to encourage both artistic rebirth and good political rule. (Guidi 1935, 82)

During Balbo's governorship, the archaeological museum was thus not subjected to major change. Making the site the centre of political authority only required partial modifications to the museum's presentation and layout, and the collection was enhanced by additional statues and mosaics from Leptis Magna and Sabratha, with both new and old displays given the most spectacular design possible. This was exemplified by the monumental entry to Balbo's office, which included an impressive statue of the Emperor Claudius from the old forum of Leptis Magna. During the Fascist era Claudius experienced a comeback, after centuries of infamy, and was commemorated as founder of the port of Ostia, embodying Rome's Mediterranean inclinations. ${ }^{8}$ However, he was probably celebrated by Balbo for his legislative role, having planned in $48 \mathrm{CE}$ to extend Roman citizenship to many of the Empire's colonies, and for his inclusive policies, as this was how the governor wanted his own proposals for the colonies to be viewed (De Felice 1988; Rochat 1986). In Balbo's study, archaeological relics were mixed in with the furnishing: funerary urns were in use as ornaments and ancient materials reused to make modern fittings and furniture such as doors, windows and the governor's vast table, which was cut from a large block of green marble unearthed by the excavations at Leptis Magna. Aside from the halls used as offices, the museum design and function were entirely retained by, for example, the Artemis of Ephesus room, the Severan dynasty room and the Liber Pater room (CTI 1940, 394). The choice of the latter themes was entirely deliberate. The dedication of a room to the house of Severus, with the busts and portraits of these emperors from Rome's African provinces, was meant to emphasise the enduring connections between the ancient colony and the mother country; Liber Pater was instead the Italic god of fertility, and the discovery in Libya of statues dedicated to him served to promote, once again, the idea of close links with the colony from classical times, and to highlight the reverence of the old colonial populations for the traditions of the mother country, encouraging their heirs to replicate this with the new Fascist Rome. ${ }^{9}$

In view of the ongoing excavations and the continuing flow of finds that could not all be incorporated among the exhibits in the Bastion of St George, in the late 1930s Balbo and the architect 
Florestano Di Fausto developed plans for a new archaeological museum, which were published in Libia, a widely read magazine, in July 1939. Construction was under way as Italy entered the war, but the new museum, which would have been a sort of passage linking the Castle's ancient atrium to the Volpi Promenade, was never completed (Stigliano 2009). The Italians never missed an opportunity to stress that they had found the Red Castle in a semi-abandoned state, just like everything else in Libya that they deemed to be of historical or artistic value. The improvement works and the range of archaeological excavations organised by Italian missions were widely used for propaganda purposes, both under Fascism and after its collapse, to support Italy's claim to its former colony, as evidence of the major commitment it had made in the name of culture and civilisation (Cresti 1996).

Aside from the finds kept in Tripoli's Museo Archeologico, the other trace of the city's Roman past was the Arch of Marcus Aurelius, which was therefore much exploited. Di Fausto was responsible for work on its isolation and improvement, setting it in the centre of a square, which was completed in 1937 (Altekamp 1995). Other museums emerged during the 1930s, but this time local ones: Bartoccini's successor as director of monuments and excavations in Tripolitania, Giacomo Guidi, was an advocate for this type and tried to ensure that objects found during digs should remain close to the archaeological site, and in some cases should even be taken back there. Despite this particular change in approach, Guidi kept faith with his predecessors' preference for the aesthetic value of an exhibit, as against its historical and archaeological features, seeing the tourist rather than the expert as the museum's interlocutor and developing this vision yet further. ${ }^{10}$ The same perspective was in evidence at the relaunching of the museum at Leptis Magna on 5 March 1931, in the presence of Badoglio, alongside the opening of the Albergo degli Scavi ('Excavations Hotel'), designed by Carlo Enrico Rava. The museum was a new, modern and appealing building that was meant to play its part in attracting visitors. Thanks to the purely aesthetic interpretation of the artefacts, which were kept on site, and to the appearance of the hotel nearby, Leptis Magna could finally draw in the ordinary tourist who did not necessarily know about archaeology; the fragments and incomplete sculptures were instead relegated to the storehouses, for the specialists' attention. The strategy of matching a local museum and a hotel, aimed at developing tourism, was also pursued at Cyrene, where in 1930 it was arranged for items previously taken to the Benghazi museum to be returned, and in 1932 work started on building a hotel designed by the architect Alessandro Limongelli. ${ }^{11}$

The director's initiatives were not always well received by the political authorities, which before Balbo's arrival seldom considered business and tourism. ${ }^{12}$ Their perspective is evident from observations made by the anthropologist Nello Puccioni, director of Florence's Museo di Antropologia ed Etnologia, who visited Libya in 1929 for anthropometric research and on 30 May visited Leptis Magna with both Badoglio and Guidi:

The dig has not yet uncovered the forum, but a beautiful and well-preserved hexagonal building with columns, with an open portico on all sides, within which there is another, circular, colonnade. ${ }^{13}$ Although this has collapsed, all its component parts have emerged, and so its reconstruction could be completed, and rapidly, if the local government should decide to allocate funding for these costs, which it regards as pointless. Badoglio, who might be a great general but cannot know much about archaeology, said that there are lots of old temples, perhaps even too many, and that there is no point dispensing cash to excavate more, while his son, visiting the ruins, declared that there was nothing of interest because everything was in pieces! (Puccioni 2019, 219)

Despite the resistance to 'dispensing cash', large excavations continued and new museums appeared alongside them. In 1932 one was set up at Sabratha, with the intention of protecting a group of statues and other finds from the Basilica of Justinian from inclement weather (Musso 
2013, 28-9). This museum had a simple and easily understandable layout, starting with Neo-Punic art, passing through Roman sculpture, and ending with Christian art (CTI 1937, 402). It thus more or less replicated the route through Tripoli's Museo Archeologico and the exhibition methodology of the Leptis Magna museum; the architect for the latter, Diego Vincifori, also worked on the Sabratha building. Prominence was deliberately given to the large Byzantine mosaic representing 'The Vineyard of the Lord', which referred to Roman Libya's Christian past, and which in Guidi's view $(1932,5)$ was only rivalled by the mosaics in Aquileia. This flooring, discovered in 1925 , must have initially been covered with seaweed and sand, 'to the wrath of visitors who had come to Sabratha specially to see the Byzantine mosaic, whose fame had already spread around the world, only to be disappointed': it was therefore necessary 'to arrange for the mosaic's conservation, reconciling the interests of archaeology, art and tourism' (5). It was lifted and taken to the edge of the archaeological site, inside the new museum built for this purpose. The use of cast inserts to fill gaps in the damaged architectural exhibits was consistent with the approach developed in the 1930s, discussed earlier, which prioritised the aesthetics of presentation and simplicity of interpretation over an exhibit's pure historical and archaeological interest (Balice 2010). However, the establishment of the Sabratha museum did mark an important shift, in that sculptures were no longer transferred to Tripoli but retained near where they were first found. This created the opportunity for more museums, and with them more opportunities for tourism; in 1934, as a result, the Ente turistico alberghiero della Libia (Libya's hotel and tourism body) decided to provide training courses for tourist guides in the Leptis Magna and Sabratha archaeological museums. Libya's range of museums was further extended in 1936 by establishment of the small museum of Ptolemais.

This brief review of the colony's archaeological museums, and use of the Roman legacy for political and imperial purposes, particularly reveals that they were in continual development, in response to frequent shifts in thinking. The museums were clearly seen as important propaganda tools and, as such, had to be constantly updated and refined.

Just one non-archaeological museum was established in Libya during its occupation by Italy, across both the Liberal and Fascist eras: the Libyan Museum of Natural History in Tripoli. This is probably the least studied or well-known of the country's museums, but its hybrid and innovative character makes it in some ways the most interesting. Its emergence followed a series of expeditions mounted by the Italian Geographical Society between 1932 and 1935, led by scientists prominent in their fields: Ardito Desio for geology, Lidio Cipriani for anthropology, Edoardo Zavattari for biology and zoology, and Elio Migliorini for linguistics. The museum owed its creation to the friendly relationship between Balbo and Desio (Falcucci 2017); the governor himself suggested that the collections could be permanently housed in Libya and an appropriate venue established for their exhibition (Desio 1937). Scholars had in fact long been requesting an institute where the Libyan finds could be gathered together, but their appeals had until then fallen on deaf ears; writing to Desio, Captain Guglielmo Narducci, an experienced collector, described the Libyan ethnographic section as 'an old dream now being fulfilled' ${ }^{14}$ There had been a clamorous call for the establishment of a collection of Libyan ethnographic material as early as 1916, in an article in the bulletin of the African Society in Naples, which was repeated at the eleventh Italian Geographical Congress in 1930 (Narducci 1937, 160). A decree establishing the museum was finally issued on 20 June 1936; Desio, meanwhile, had been appointed its director and editor of its journal. The territory was thus at last connected to its ethnographic, geological, botanical and zoological heritage, hitherto scattered across many museums in the Italian peninsula, giving the visitor a comprehensive overview of the Libyan colony in a museum that was hailed, from its inception, as one of the most important in North Africa. ${ }^{15}$ 
On 26 March 1937, the Libyan Museum of Natural History was ceremonially opened in the presence of Giuseppe Bottai, then Italy's minister for National Education, as well as Balbo. The press provided ample coverage of the event, and not just as an item of local Tripoli news: L'Azione coloniale, an important weekly magazine published in Rome, provided a full report emphasising the new institution's importance:

The museum makes a notable contribution to improving the colony's facilities in the cultural sphere, and knowledge of Libya in the scientific sphere is bound to impress the public, which usually considers museums to be impenetrable, static, and dead. ... Each branch of the natural sciences has here a base not only for scientific study, but also for all the practical applications intrinsic to the colony's life and prosperity. Currently, the geological section is engaged in intense work searching for phosphates and potassium salts, two first-rate fertilisers for which we are largely dependent on other countries; since last year, geological and mineral missions have covered thousands of kilometres ... a truck has even been equipped as a chemical laboratory.... Similarly, the zoological section has been assigned research in agricultural entomology, to employ a scientific approach to the battle against crop parasites. ... Marine biology research will allow fishing to be practised scientifically.... Over and above all the practical applications, which are leading the way for the [Libyan] colony's economy and importance, are the findings in purely scientific terms. (Azione Coloniale 1937)

The intention was that the museum would be more than just a reference point in scientific terms; instead, its approach was to be proactive. Introducing the first issue of its journal, the Annali del Museo libico di storia naturale, Desio described the museum's arrival as 'the act of creation of a new Fascist centre for research and culture on the African shores of our Mediterranean, to take its place within the grand plan for Libya's economic development and spiritual advancement' (1939). Potentially, the museum would stimulate the colony's economic development by fostering research into minerals, phosphates, raw materials and water sources. The second element, Libya's 'spiritual advancement', was being promoted through Italy's gift of dignity by creating a museum and thereby, for the first time in the field of natural sciences, allowing retention of collected materials overseas. Nélia Dias $(2000,19)$ discusses how nature and culture were presented alongside each other in colonial museums in order to demonstrate the richness of colonised territories, which their rulers intended to exploit: the intention to instruct was thus mixed together with a display of economic prosperity, resource utilisation and colonial rule.

In 1940 the museum had 70,078 visitors, of whom 43,220 were 'italiani' and 26,685 'arabi'. It was also fairly successful with schoolchildren, the Corriere di Tripoli (1942) reported. The statistics convey the idea of a museum whose visitors included local people, something that the newspaper seemed proud of: they perhaps came from the elite close to the Italian authorities, who were willing to subject themselves to the museum's 'game of mirrors' in visiting an exhibition that told the story of their own country, but through the colonisers' eyes. No information was given about the visitors' social background, although Desio insisted more than once, albeit partly for rhetorical effect, that the museum's donors, just like its visitors, were 'dignitaries, officials, soldiers, clerks and workmen' (1939). Continuing in this bombastic tone, but nevertheless providing a sense of the real plan of cultural operations in Libya, Desio discussed Balbo's endeavours, and thereby indirectly commented on his own: 'he has created the fatherland for the local populations'.

\section{An imperial narrative: museums and temporary exhibitions in Italian East Africa}

On 9 May 1936, to tumultuous applause, Mussolini announced to his Italian enthusiasts nothing less than 'the return of the empire to Rome's hills of destiny. Italy finally has its empire. A Fascist empire ... empire of peace ... empire of civilisation and humanity' $(1959,269)$. Thereafter, the regime's propaganda was relentless in its depiction of Italians as noble and unselfish pioneers 
who generously brought roads, schools and hospitals to a backward region, and as heroic workers or 'soldier-colonists' who transformed desolate wastes into gardens or fertile and productive land (Deplano 2015, 82-116). After its military conquest, Ethiopia's 'fascistisation', especially in terms of display, proceeded at record speed: less than a year later, in February 1937, the first agricultural show, organised by the local Fascist Federation, was held in Addis Ababa. Livestock was described as one of Ethiopia's greatest riches (Massi 1938), to the extent that it was presented as the solution to Italy's problem of importing meat from abroad; the show was apparently a success, giving breeders the chance to meet and compare their stock-rearing methods (Illustrazione Italiana 1937). That same year, Puccioni $(1937,11)$ wrote about a zoo being built in Mogadishu, specialising in antelopes, in the 'Pozzo Cave' area.

The organisation of this type of show indicates the efforts the regime was making to return the normality of ordinary existence to a world that was in reality still pervaded by civil war and rebellion, which had never been stamped out and if anything were increasing. In addition, it draws attention to the importance of shows and exhibitions in the attempt to give Fascist features to the new colony, in Fascist language a 'province', in which the Italian colonisers were expected to follow the example of 'the civilising policy of Rome' (Mussolini 1935). Despite the limited period of Italian rule, many initiatives of this sort followed (Larebo 2005). The Ethiopian Empire had been presented to the Italian population as a feudal country in which a select circle held the wealth to the detriment of a people reduced to slavery, thus justifying its conquest and liberation (Satta 2016); Emperor Haile Selassie had shown himself unable to administer the country's great riches, but the Italians, inspired by the 'soldier-peasants' of ancient Rome, supposedly had the capacity to put this land, so rich in potential, to good use (Conti Rossini 1935). ${ }^{16}$ Obviously, the realities of the new Italian Empire's situation were never allowed to intrude: there was no acknowledgement of the military difficulties the Italians experienced (Caprotti 2014; Pes 2010, 141-3), nor of the meagre advances in regard to the country's infrastructure (Mattioli 2009) and in the struggles against serfdom and disease. In reality, control of the Ethiopian populations outside the capital was minimal, with new hotbeds of revolt emerging daily in outlying areas; Italian involvement therefore focused on the capital and the other main centres, where most of the Italian citizens lived, and where it was easier to maintain the fiction of territorial command.

Addis Ababa, especially, had to represent the strength and greatness of Fascist Italy's latest endeavour. The city was declared capital of the Empire in the decree-law of 1 June 1936, and as soon as possible provisions were made to give it a Fascist Party base, an OND office and a Fascist Cultural Institute, and to organise youth and women's sections of the Fascist Party (Pes 2010, 173-4). In the Fascist programme, very little of which was implemented (de Napoli 2018, 355; Mattioli 2009), Addis Ababa was supposed to become not only the political centre of Italian East Africa (Africa Orientale Italiana: AOI), but also the central hub for all the Empire's commercial and industrial activity. According to the AOI guide published by the Consociazione Turistica Italiana (CTI, formerly Touring Club), the plan was 'to create a new Italian city, clearly distinguished from that of the native population and built in accordance with standards of monumentality and grandeur appropriate for the capital of the Italian Empire' (CTI 1938, 119). The actual outcomes of the government's policies in Ethiopia, however, were not as important as the propaganda in Italy itself regarding these measures, which were presented as benefitting the citizens of what was supposed to be one of the Empire's provinces rather than a colony. At the dozens of exhibitions held in Italian cities, well-used land, the educational system, and improvements to health services were presented as the impressive results that the regime had rapidly achieved; displays featured both the country's natural resources and the victorious struggle of civilisation that the regime had conducted against the backward and feudal Abyssinian 
government. The many exhibitions of this nature are too numerous to list here, but, for example, a 'Mostra dell'Etiopia Italiana' was held in Florence from 23 May to 14 June 1936 (thus starting just some two weeks after conclusion of the military conquest); in spring of the same year Ethiopia had been well represented at an exhibition of Fascist colonial books in Rome (Goglia 1985, 274); many small exhibitions dedicated to Ethiopia, up and down the peninsula, were set up to coincide with 'Colonial Day' in 1936; and at that year's Milan Fair a pavilion was dedicated to the newly acquired colony. In 1937, in June, a 'Mostra dell'Impero' (Empire Exhibition) was staged in Padua, as were similar events in Ravenna and Varese in 1938, and in Udine in July 1939 (Azione Coloniale 1939). ${ }^{17}$ The Empire was strongly represented at the major 'Mostra del minerale autarchico' ('Exhibition of Mineral Self-Sufficiency') held in Rome in 1938, and in Naples at the 'Mostra Triennale delle Terre d'Oltremare' (Triennial Overseas Lands Exhibition), but also at local fairs such as Verona's 'Agriculture and the Horse' festival in 1937. It was thus not just to be understood as a military conquest to gratify a handful of enthusiasts in the ministries, but was intended to 'arrive in the provinces', to convince Italians of its undoubted worth and to be owned by all.

Just as much attention was lavished on putting the great progress achieved by the Empire on display within the colonies themselves, by means of both temporary and permanent exhibitions, or plans for the latter. The first major show in East Africa had been held in Asmara in 1905, for the first Colonial Congress, and was staged in an 'Art Nouveau' pavilion that emphasised Governor Ferdinando Martini's ambition to place this event up alongside major European exhibitions. It was organised in ten sections: Eritrean products suitable for export to Italy, European products most in demand in Eritrea and neighbouring regions, ethnography, livestock, agriculture, minerals, technology, law, cartography and photography (Zaccaria 2002).

In regard to museums, King Victor Emmanuel III was present in November 1934 for the opening of the Museo della Garesa (now the National Museum of Somalia) in Mogadishu's restored castle, previously the seat of the Sultan of Zanzibar (Azione coloniale 1934). The first plan for a museum in the colonies that we know about was also connected to Somalia: a plan to build a History Museum for Somalia in Mogadishu was mentioned in a document of 1909 regarding the cultural activity of Italians in Africa, unearthed during research in the archives of the defunct Ministry for Italian Africa. ${ }^{18}$ The 'noble and generous' idea of the museum, heavily promoted by the military, had emerged in the summer of 1908 when the Abyssinian authorities returned items once owned by 'the late lamented Captains Molinari and Bongiovanni', found in Bardale (Tittoni 1908), to the Italian legation in Addis Ababa. ${ }^{19}$ The idea was to exhibit these in Mogadishu, alongside flags and other items linked to the military campaigns. This project long remained on paper only, and Mogadishu had to wait a further twenty-five years for the opening of the Somali museum; however, the document offers a valuable indication of the importance already being awarded to cultural and museological policy, which was the subject of debate and planning, at the beginning of Italy's 'colonial adventure' (as it was termed) in Somalia. ${ }^{20}$ The Museo della Garesa, with library attached, was a project favoured by both the colony's secretary-general Francesco Caroselli and its governor Maurizio Rava. ${ }^{21}$ In a strange parallel with contemporaneous events in Libya, it was located in the old centre of power from which the ruler of Zanzibar had issued demands for tax payments (Caroselli 1934). According to Caroselli, the museum was 'not just of interest to the curious and to tourists: it demonstrates that the colonial endeavours of us Latins do not stop with utilitarian forms of exploitation, but go deep into the history and soul of the country in order to know and develop it, pursuing the talent of our race' $(1934,726)$. Pure propaganda apart, the museum's foundation can be understood as an attempt to strengthen the shared identity of Italians in Somalia and to project this idea onto the population as a whole, which was perceived as more or less uniformly backward. However, some distinction was made 
between, on the one hand, Somalis of Arab descent, typically traders, who were presented as the most developed and technologically advanced ethnic group by virtue of their age-old relations with the Arabian Peninsula and their travels towards the Indian Ocean, and, on the other, the country's remaining ethnic groups, typically poorer herdsmen and peasants; these groupings fell within a hierarchy and racial order that proved particularly useful to the Italians, in regard to both the economy and control of the Somali people. ${ }^{22}$ The museum therefore both presented the story of the pioneers, including their economic successes (especially those achieved by the Duke of Aosta's Società Agricola Italo-Somala) and Italian anti-slavery activity, and exhibited ethnographic and zoological material from Somalia (Museo della Garesa 1934, 5). The displays portrayed Somalis as a childish people, whose 'curious' objects, such as drums and religious items used in ritual dances or for treating illness, were over-represented in relation to objects customarily used for a specific function. Exhibits were given neither context nor description and artefacts from different ethnic groups were often mixed together; the clear intention was to bolster the racist policy of the regime towards the indigenous peoples, who were presented as primitive, backward and unproductive, at least until the Italians arrived. The decorations inside the museum, in which, according to the anthropologist Nello Puccioni, 'one hardly knows whether to more admire the innocence of representation or the imagination in composition' $(1937,13)$, had been undertaken by indigenous artists, with the clear intention of amazing the visitor: they related to adventurous and alarming visions and to classic 'big game' themes, highlighting the abundance of wildlife by 'representations of the local fauna with figures of huge crocodiles opening their gaping jaws, into which terrified antelopes unwittingly throw their whole bodies' (13).

It is striking that while the fauna was subjected to meticulous cataloguing, the Somalis were quickly dismissed as 'tutti uguali' ('all the same'). Distinctions between ethnic groups were ignored and little effort was made to truly understand the subjugated peoples, whose objects were not seen as having worth; it was no coincidence that Puccioni only described the Arabic manuscripts as 'ancient and valuable' $(1937,13)$. The museum revealed a whole range of prejudices and a large degree of ignorance among its curators, illustrated by the fact that the displays did not adequately understand or reflect the importance of male jewellery use (Declich 1992, 156). Because of their sophistication, Puccioni declared the pieces to be 'almost all of the style belonging to Arab jewellery work' $(1937,14)$, discounting the contribution of non-Arab Somali craftsmen.

The Museo della Garesa was the only museum project that actually came to fruition in the AOI during this period. The CTI guide of 1938 reported that plans were being developed in Addis Ababa for a 'Museo dell'Impero', whose first small group of objects was being exhibited in a reception room on the ground floor of the former Ethiopian monarch's palace $(1938,492)$. In 1940, in the Annali dell'Africa Italiana, there was news of a planned museum, never realised, that was to be based on the government's ornithological collection in Addis Ababa (with more than 300 birds) and the collection of the hunting inspectorate (1940c, 1234). This project fell within the scope of plans to develop wildlife and hunting tourism, as in Libya, which provided the basis for new local laws on hunting (Toschi 1941). Moreover, a permanent archaeological unit was established in Axum in 1939, consisting of an archaeologist, a restorer and an architect, to collect the findings from excavations in a temporary base pending government funding and the creation of a directorate for archaeology in Ethiopia (Annali dell'Africa Italiana 1940b, 962-964); some of the finds were sent to the museum in Asmara, which had also been improvised in rooms within the governor's palace. While in Libya archaeology, ethnology and physical anthropology had all been employed to justify military conquest, the Ethiopian War went ahead with little of this scientific rationalisation, employing a racist rhetoric that was by then well developed. 
Among many proposals, few of them fulfilled, the most visionary project for the AOI was undoubtedly the Mogadishu aquarium, conceived by Hans Grieco, who was also a member of the research committee for the planned Triennial Overseas Lands Exhibition in Naples. Planned in 1939 by Grieco and Somalia's governor Caroselli, the aquarium was to have been a tourist attraction as well as a research centre for tropical marine fauna. It was included in the plan to improve and promote the Empire's ports, alongside the excavations programme in Ostia and the Naples exhibition, and was to have emphasised the Italian talent for ruling the seas and vocation for exploration. Research trips were organised to investigate aquatic life in the lakes and rivers across the AOI with a view to finding suitable species to exhibit in the aquarium, which was intended 'to fulfil three functions: scientific, economic and informative' (Cocchia 1941), enabling the study of fauna, its reproduction in order to restock Italy's aquaria, and its exhibition. Had it been established, it would have been Africa's first hydrobiological centre, modelled on the aquarium in Naples (founded in 1872) and the Triennial Exhibition's tropical aquarium planned by Carlo Cocchia, who would also have been involved in Mogadishu. There was no shortage of ideas for its design: located on the seafront, resting on piling that would raise it just above the water, the aquarium would have had a single floor with rooms containing tanks about six feet deep and open at the top, a library, and a laboratory. In the tanks, whose 'internal decoration is the most important element for exhibition purposes', 'artificial rocks and rock arches' would alternate; this aspect, Cocchia thought, deserved particular attention, because 'this [internal organisation] provides the visitor with their emotional response ... and this is what leads to one aquarium being judged better than another' $(1941,931)$. In his view 'every tank should be an evocative staged setting', not only because of the beauty and rarity of the creatures exhibited but 'also through the lighting installed, the colours chosen, and the depth of the various fields of perspective'; effects never previously boasted by an aquarium would be created by the use of film projections on the water, scenery panels, and colour.

The years of the Empire were clearly a time of fertile planning activity and cultural and scientific endeavour in both Ethiopia and Somalia. Moreover, various scientific missions were organised, including, notably, the Italian Royal Academy's expedition to Somalia in 1935, entrusted to Nello Puccioni and Paolo Graziosi, some of whose findings can be seen in the collections of Florence's anthropological museum (Zavattaro 2014); the expedition by Giotto Dainelli and Lidio Cipriani to Lake Tana in 1937 (Surdich 1991); and Edoardo Zavattari's expeditions to the great equatorial lakes between 1937 and $1940 .^{23}$

While the agricultural show organised not long after the Italian forces had arrived in Addis Ababa, discussed earlier, was intended to inject a sense of stability and publicise the wealth of the recently acquired territory, exhibitions were certainly not limited to the economic sphere. The Empire's many riches were celebrated in the most varied exhibition projects, which included the 'Militia Show' in Addis Ababa, requested by the Fascist Blackshirts' high command in the AOI to demonstrate 'the contribution of courage and blood that the Fascist legionnaire spirit made to the war for conquest of the Empire' (Azione Coloniale 1940a); the 'Empire's First Art Exhibition' in Addis Ababa (Azione Coloniale 1938); the OND's art exhibition in Gondar, staged in the city's recently restored Bakaffa Castle, from which the best work was supposed to be selected and sent to represent the Amhara region at the Triennial Overseas Lands Exhibition in Naples; Eritrea's 'First Art Exhibition', organised in the AGIP petrol company's building in Asmara (Corriere Eritreo 1939); the 'Mostra autarchica' ('Self-sufficiency Show') for the Shewa region (Azione Coloniale 1940b), which related to the mother country's self-sufficiency programme; and a similar event for Galla-Sidamo, held in Jimma in the spring of 1940 (Azione Coloniale $1940 c)^{24}$ 


\section{Conclusion}

Giovanni Pinna (2009) argues that the museums of the Fascist era made no fundamental innovations in Italian museology, respecting the contents of the traditional museum. However, they did bring changes to its form, making exhibitions simpler and showier, as illustrated by the first 'Exhibition of the Fascist Revolution' and its enormous success (Muntoni 1990).

In just a few years, the regime had the ability to conceive, plan, and to a lesser extent realise a large number of events linked to the newly born empire, in the colonies just as in Italy itself. Having reached the end of this discussion, one is left wondering what the colonial museum experience might have been if the many 'construction sites' for the nation - sometimes curious, but always carefully considered for their communicative effectiveness - had all reached their fulfilment.

Translated by Stuart Oglethorpe (stuart.oglethorpe@gmail.com)

\section{Acknowledgements}

I would like to thank the anonymous reviewers for their helpful comments and excellent advice, Claudia Baldoli and the other editors of this special issue for their guidance, and Stuart Oglethorpe for his clarity during the translation process.

\section{Note on Contributo}

Beatrice Falcucci is a $\mathrm{PhD}$ candidate at the University of Florence, undertaking research into the colonial collections in Italian museums. She has published articles in Museologia Scientifica, Cahiers d'Histoire and Journal of the History of Collections, and has co-edited (with Fausto Barbagli) the volume 'Affrica all'acqua di rose'. I diari delle missioni antropologiche in Cirenaica del 1928-1929 by Nello Puccioni (Florence: Polistampa, 2019).

\section{Notes}

1. Archivio Ardito Desio (hereafter AAD), Faldone 71B, 1936-1937, note by Ardito Desio. (The archive was private and held in Rome, but has now been donated to the museum in Udine.)

2. For the archaeological value and propaganda use of the Museo delle Sporadi, see Gioia (1939). Rhodes and Libya were often placed together in the discourse on the 'return of Rome'. According to an article of 12 May 1912 in l'Illustrazione Italiana, 'Italy has written new pages of history in the last week by taking Leptis Magna [on the Libyan coast], birthplace of the emperor Septimius Severus, and Rhodes in the historic Greek Archipelago ... its naval strength has been deployed in those islands where the seagoing daring of Genoa and Venice shone in ancient times' (Simonetti 1963, 88). Any inconvenient signs of the recent Ottoman past were eliminated from the Hospital by 'an act of healthy liberation', as the archaeologist and curator Giuseppe Gerola reported to the Ministry of Foreign Affairs (Troilo 2012).

3. For the history of this castle, see Santoro (2003).

4. Aurigemma described the statue of the goddess Roma as 'particularly evocative in symbolic value in the eyes of the new colonists' $(1919,93)$.

5. For the director's explanation of his approach, see Bartoccini (1926).

6. Ten years after Brasini's restoration, Guidi judged it both extravagant and inappropriate (1935, 20-21).

7. Angelo Piccioli, an official in the Ministry for the Colonies, referred to a plan of 1930 for transformation of the Red Castle as a whole into one single large History Museum for Libya; this came into being in the 1950s (Falcucci 2017).

8. The many books published in the 1930s on Claudius include a monograph by Arnaldo Momigliano (1932), who also wrote the entry on Claudius in the Enciclopedia Treccani (1931), which emphasises his rehabilitation under Fascism. 
9. It is perhaps no coincidence that Liber Pater was also celebrated by Septimius Severus, who had him portrayed on coinage as the protector of his family; see Bruhl (1953).

10. In Guidi's view, exhibitions did not have to be in chronological order, nor arranged by context; they simply had to be aesthetically pleasing. In his design for the museum, for example, he split up the group of sculptures from the Baths of Hadrian and separated the panels from the Villa of the Nile frigidarium so that they were in two different rooms; for a description, see CTI $(1937,336-7)$.

11. At the excavations for the Great Baths of Cyrene, a small on-site depository had already been set up in 1914 to protect the items found before the digging officially started three years later; the most valuable finds, however, were transferred to Benghazi. The Benghazi museum, in Via Santa Barbara, was described by the anthropologist Nello Puccioni, visiting in March 1929, as a small museum 'of three rooms' $(2019,157)$, but in 1940 was referred to as 'one single hall' with few exhibits (CTI 1940).

12. Between the two-year periods of 1929-30 and 1936-7, due to Balbo's enthusiasm for Roman archaeological finds as a spur to tourism, funding for archaeological excavations more than tripled, rising from about 700,000 lire to the considerable sum of about 2.3 million (Forti 2009).

13. The building Guidi had discovered, described in Puccioni's diary (2019), was the market.

14. AAD, Faldone 71B, Letter from Guglielmo Narducci to Ardito Desio, 12 September 1936.

15. The dispersal of exhibits had had many critics, including Edoardo Zavattari (1934), who deplored the dismantling of collections that needed to be analysed as a whole if their study was to lead to a true understanding of the colonies and the advancement of science.

16. For discussion of the image of the Roman and Fascist 'soldier-farmer', see Larebo (1994, 65-7).

17. For the Padua exhibition, see the report in Il Resto del Carlino, 19 June 1937, discussed by Pes (2010, 127).

18. Archivio Storico Diplomatico, Ministero Affari Esteri (hereafter ASD MAE), Fondo ex Ufficio Studi Ministero dell'Africa Italiana, Miscellanea, Fascicolo Azione Culturale.

19. ASD MAE, Ministero dell' Africa Italiana, vol. III, Busta 41, 'Museo Storico (in costruzione) in Somalia' (1909).

20. Italy took on direct management of the Somalian protectorate only in 1905, and by 1908 had completed the process of formalising its rule.

21. Evidence of the important documents conserved in the library, some of which were exhibited in the museum, can be found in the ASD MAE archive. The colonial authorities provided the museum with documents judged to be significant, especially in connection with slavery and its abolition. The same collection conserves some of these documents in Arabic and Amharic and their translation. See ASD MAE, Direzione generale della Somalia 1890-1933, Fascicolo 5. Caroselli, through the Istituto Coloniale Fascista, had encouraged its members and travellers to donate items to the museum (Declich 1992, 146)

22. On the arbitrary classification applied by colonisers in relation to the colonised, see the concept of 'census' discussed by Benedict Anderson (1991, 163-85).

23. A note in the Annali dell'Africa Italiana (1940a) emphasised the importance of Zavattari's research into demography and race, making explicit reference to the magazine La Difesa della Razza, for which he was a regular contributor.

24. For the exhibition in Gondar, see ASD MAE, Fondo ex Ufficio Studi Ministero dell'Africa Italiana, Miscellanea, Fascicolo Azione Culturale, typescript.

\section{References}

Altekamp, S. 1995. 'L'azione archeologica fra indirizzo scientifico e intervento politico: il caso dell'archeologia libica 1911-1943'. Quaderni di Storia 41: 101-14.

Anderson, B. 1991. Imagined Communities: Reflections on the Origin and Spread of Nationalism, rev. ed. London: Verso.

Annali dell'Africa Italiana. 1940a. 'La ricognizione scientifica'. Annali dell'Africa Italiana 3 (1): 956. Annali dell'Africa Italiana. 1940b. 'Ricerche archeologiche'. Annali dell'Africa Italiana 3 (1): 962-4. Annali dell'Africa Italiana. 1940c. 'La costruzione dell'Impero'. Annali dell'Africa Italiana 3 (1): 1234. Arthurs, J. 2015. 'The Excavatory Intervention: Archaeology and the Chronopolitics of Roman Antiquity in Fascist Italy'. Journal of Modern European History 13: 44-58. 
Aurigemma, S. 1919. 'L'inaugurazione del R. Museo archeologico di Tripoli'. L'Illustrazione coloniale 1 (3): 93-5.

Aurigemma, S. 1923 'Il castello di Tripoli di Barberia'. Rivista Coloniale 18: 191-220.

Azione Coloniale. 1934. 'Il trionfale viaggio del Sovrano nella fedele ed operosa Somalia'. 19 November. Azione Coloniale. 1937. 'SE. Balbo e SE. Bottai inaugurano il Museo di storia naturale tripolino'. 1 April. Azione coloniale. 1938. 'La I Mostra d'Arte Coloniale ad Addis Abeba inaugurata da S.E. Teruzzi'. 23 July. Azione Coloniale. 1939. 'La mostra dei prodotti dell'Impero'. 10 August.

Azione Coloniale. 1940a. 'La Mostra della Milizia'. 1 February.

Azione Coloniale. 1940b. 'L'opera dei pionieri fascisti alla Mostra autarchica dello Scioa'. 8 February.

Azione Coloniale. 1940c. 'La Mostra autarchica del Galla e Sidama'. 4 April.

Balice, M. 2010. Libia: Gli scavi italiani: 1922-1937. Restauro, ricostruzione o propaganda? Rome: L’Erma di Bretschneider.

Bartoccini, R. 1923. Guida del Museo di Tripoli. Tripoli: Tip. Scuola d'Arti e Mestieri.

Bartoccini, R. 1926. 'Il Museo di Tripoli'. In La rinascita della Tripolitania, edited by G. Volpi, 565-8. Milan: Mondadori.

Bruhl, A. 1953. Liber Pater. Origine et expansion du culte dionysiaque à Rome et dans le monde romain. Paris: de Boccard.

Cagnetta, M. 1991-1992. 'L'impronta classica dell'ideologia coloniale italiana'. Lezioni di Storia del Colonialismo. Materiali di lavoro 2-3: 199-211.

Capresi, V. 2007. 'The New Face of Tripoli (Libya) in the Thirties'. Architectura 37 (1): 95-117.

Caprotti, F. 2014. 'The Invisible War on Nature: The Abyssinian War (1935-1936) in Newsreels and Documentaries in Fascist Italy'. Modern Italy 19 (3): 305-21.

Caroselli, F.S. 1934. 'Il Museo della Somalia'. Rivista delle Colonie Italiane 9: 724-6.

Cocchia, C. 1941. 'L'acquario di Mogadiscio'. Annali dell'Africa Italiana 4 (3): 925-31.

Consociazione Turistica Italiana (CTI). 1937. Libia. Milan: CTI.

Consociazione Turistica Italiana (CTI). 1938. Guida d'Italia della Consociazione Turistica Italiana: Africa Orientale Italiana. Milan: CTI.

Consociazione Turistica Italiana (CTI). 1940. Italia meridionale e insulare - Libia. Milan: CTI

Conti Rossini, C. 1935. 'L'Etiopia è incapace di progresso civile'. La Nuova Antologia, 16 September: 171-7.

Corriere di Tripoli. 1942. 'Il Museo di Storia Naturale al suo quinto anno di vita'. 26 March.

Corriere Eritreo. 1939. 'La I Mostra d'arte dell'Eritrea sarà inaugurata domani ufficialmente, 30 espositori con oltre 200 opere nell'importante rassegna d'arte'. 25 November.

Cresti, F. 1996. Oasi di italianità. La Libia della colonizzazione agraria tra fascismo, guerra e indipendenza (1935-1956). Turin: SEI.

Declich, F. 1992. 'La Somalia coloniale alla Garesa'. In L'Africa in vetrina. Storie di musei e di esposizioni coloniali in Italia, edited by N. Labanca, 145-60. Treviso: Pagus.

De Felice, R. 1988. Il fascismo e l'Oriente. Arabi, ebrei e indiani nella politica di Mussolini. Bologna: Il mulino.

de Grazia, V. 1981. The Culture of Consent: Mass Organization of Leisure in Fascist Italy. Cambridge: Cambridge University Press.

de Napoli, M. 2018. 'La trasformazione italiana di Mogadiscio fra le due guerre. Piani e progetti per una visione europea della capitale somala (1905-1941)'. In La Città Altra. Storia e immagine della diversità urbana: luoghi e paesaggi dei privilegi e del benessere, dell'isolamento, del disagio, della multiculturalità, edited by F. Capano, M.I. Pascariello and M. Visone, 349-58. Naples: Federico II University Press.

Deplano, V. 2015. L'Africa in casa. Propaganda e cultura coloniale nell'Italia fascista. Florence: Le Monnier.

Desio, A. 1937. 'Il Museo libico di storia naturale'. In Atti del terzo Congresso di Studi Coloniali, FirenzeRoma, 12-17 aprile 1937, 9 vols, vol. 5, 264-9. Florence: Sansoni.

Desio, A. 1939. 'Presentazione'. Annali del Museo Libico di Storia Naturale 1 (1): 4-5.

Dias, N. 2000. 'Musées et colonialisme: entre passé et présent'. In Du Musée colonial au Musée des Cultures $d u$ Monde, edited by D. Taffin, 15-33. Paris: Maisonneuve et Larose. 
Di Lauro, R. 1938. Corso di storia e politica coloniale. Milan: Bocca.

Falasca Zamponi, S. 2003. Lo spettacolo del fascismo. Soveria Mannelli: Rubbettino.

Falcucci, B. 2017. 'Il Museo di Storia Naturale di Tripoli, realtà contemporanea di un museo coloniale'. Museologia Scientifica 11: 87-96.

Falcucci B. 2019. 'La terra feconda della diciassettesima regione del Regno d'Italia. La colonizzazione in Libia negli anni Trenta tra agricoltura e spettacolo'. In Multiethnic Cities in the Mediterranean World. History, culture, heritage, edited by M. Folin and R. Tamborrino, 395-403. Turin: Associazione Italiana di Storia Urbana.

Forti, S. 2009. 'Il contributo alla documentazione del Fondo Caputo per la ricostruzione dell'attività archeologica italiana in Libia'. Quaderni di Archeologia della Libya 20: 171-7.

Gabrielli, G. 2013. 'Finding out about the Colonies: The Role of Schools, between the 1800s and 1900s, in Establishing an Italian Colonial Identity: The State of the Research'. History of Education and Children's Literature 8 (1): 319-41.

Ghezzi, C. 2003, Colonie, coloniali. Storie di donne, uomini e istituti fra Italia e Africa. Rome: Istituto italiano per l'Africa e l'Oriente.

Gioia, P. 1939. 'L'impero, la Libia e Rodi all'esposizione internazionale di New York'. Rivista delle colonie 13 (8): 1625-30.

Goglia L. 1985. Storia fotografica dell'Impero fascista, 1935-1941. Rome-Bari: Laterza.

Guidi, G. 1932. Il Museo Sabratense. Tripoli: Cacopardo.

Guidi, G. 1935. Il restauro del Castello di Tripoli negli anni XII e XIII. Tripoli: Cacopardo.

Illustrazione Italiana. 1937. 'La mostra zootecnica di Addis Abeba'. 21 February.

Labanca, N., ed. 1992. L'Africa in vetrina. Storie di musei e di esposizioni coloniali in Italia. Treviso: Pagus.

Labanca, N. 2000. 'La Libia nelle guide turistiche italiane del periodo coloniale'. In Permanenze e metamorfosi dell'immaginario coloniale in Italia, edited by E. Castelli and D. Laurenzi, 61-78. Naples: Edizioni Scientifiche Italiane.

Labanca, N., ed. 2003. La Libia nei manuali scolastici italiani (1911-2001). Rome: Istituto italiano per l'Africa e l'Oriente.

Larebo, H.M. 1994. The Building of an Empire: Italian Land Policy and Practice in Ethiopia, 1935-1941. Oxford: Clarendon.

Larebo, H. 2005. 'Empire Building and its Limitations: Ethiopia (1935-1941)'. In Italian Colonialism, edited by R. Ben-Ghiat and M. Fuller, 83-94. New York: Palgrave Macmillan.

Mancosu, G. 2014. 'L'Impero visto da una cinepresa. Il reparto foto-cinematografico "Africa Orientale" dell'Istituto Luce', in Quel che resta dell'Impero. La cultura coloniale degli italiani, edited by V. Deplano and A. Pes, 259-78. Sesto San Giovanni: Mimesis.

Massi, E. 1938. 'Economia dell'Africa Italiana'. Rivista Internazionale di Scienze Sociali 9 (3): 434-58.

Mattioli, A. 2009. 'Urbanistica e architettura fasciste tra edificazione e demolizioni nell'Africa Orientale Italiana'. I sentieri della ricerca 9-10: 329-47.

McLaren, B.L. 2006. Architecture and tourism in Italian colonial Libya: An Ambivalent Modernism. Seattle: University of Washington Press.

Mignemi, A. 1984. Immagine coordinata per un impero. Etiopia 1935-1936. Turin: Forma.

Momigliano, A. 1931. 'Claudio imperatore'. In Enciclopedia italiana, vol. 10. Rome: Treccani.

Momigliano, A. 1932. L'opera dell'imperatore Claudio. Florence: Vallecchi.

Muntoni, A. 1990. 'Esposizioni e regime: ideologia e colonialismo'. Quaderni Di: di-segno come scrittura/ lettura 11: 61-74.

Munzi, M. 2001. L'epica del ritorno. Archeologia e politica nella Tripolitana italiana. Rome: L'Erma di Bretschneider.

Munzi, M. 2016. 'Archeologia e guerra in Libia. Archeologi e militari nella guerra italo-turca e nella campagna del Nord Africa'. In Under Western Eyes: Approches occidentales de l'archéologie nord-africaine (XIXe-XXe siècles), edited by H. Dridi and A. Mezzolani Andreose, 85-108. Bologna: BraDypUs.

Museo della Garesa. 1934. Museo della Garesa. Catalogo. Mogadishu: Regio Governo della Somalia. 
Musso, L. 2013. “'Un nuovo e degno Museo archeologico sta sorgendo a Sabratha ...”. Dal Museo Archeologico di Tripoli ai musei di Leptis Magna e di Sabratha'. In Il Museo di Sabratha nei disegni di Diego Vincifori. Architettura e archeologia nella Libia degli anni Trenta, edited by L. Musso and L. Buccino, 19-33. Florence: All'Insegna del Giglio.

Mussolini, B. 1935. 'Le Province Africane'. Il Popolo d'Italia. 7 June.

Mussolini, B. 1959. Opera omnia di Benito Mussolini, vol. 27, edited by E. Susmel and D. Susmel. Florence: La Fenice.

Narducci, G. 1937. 'La sezione etnografica del Museo Libico di Storia naturale di Tripoli'. In Atti del terzo Congresso di Studi Coloniali, Firenze-Roma, 12-17 Aprile 1937, 9 vols, vol. 6, 160-7. Florence: Sansoni.

Pes, A. 2010. La costruzione dell'impero fascista. Politiche di regime per una società coloniale. Rome: Aracne.

Pinna, G. 2009. 'I musei nelle dittature: Germania, Italia, Spagna'. Nuova Museologia 21: 2-33.

Puccioni, N. 1937. Giuba e Oltregiuba. Florence: Sansoni.

Puccioni, N. 2019. 'Affrica all'acqua di rose'. I diari delle missioni antropologiche in Cirenaica del 19281929, edited by B. Falcucci and F. Barbagli. Florence: Polistampa.

Ricci, L. 2005. La lingua dell'Impero. Comunicazione, letteratura e propaganda nell'età del colonialismo italiano. Rome: Carocci.

Rochat, G. 1986. Italo Balbo. Turin: UTET.

Santoro, R. 2003. 'Il Castello di Tripoli'. Quaderni di architettura della Libya 18: 435-40.

Satta, G. 2016. 'Civiltà di Roma e barbarie abissina. La propaganda antischiavista e la guerra d'Etiopia'. Parole-chiave 55: 67-76.

Simonetti, F., ed. 1963. L'illustrazione italiana. 90 anni di storia. Milan: Garzanti.

Sindacato Nazionale fascista tecnici agricoli. 1937. Agricoltura e impero. Conferenze tenute al Corso di organizzazione tecnico-agricola-coloniale. Roma, 5 settembre- 4 Ottobre 1936, Firenze, 5-13 novembre 1936. Rome: Tip. Sallustiana.

Stigliano, M. 2009. Modernità d'esportazione. Florestano di Fausto e lo stile del costruire nei territori italiani d'oltremare. Bari: Poliba Press.

Surdich, F. 1991. 'Le spedizioni scientifiche italiane in Africa orientale e in Libia durante il periodo fascista'. In Le guerre coloniali del fascismo, edited by A. Del Boca, 443-68. Rome-Bari: Laterza.

Surdich, F. 2000. 'I musei coloniali fra storia e progetto'. In Per una nuova museologia. Atti del Convegno internazionale 'La funzione educativa del museo. Bergamo, Accademia Carrara, 16 dicembre 1998', edited by G. Pinna and S. Sutera, 115-23. Milan: ICOM.

Tittoni, T. 1908. 'Discorso pronunziato alla Camera dei Deputati da S.E. il ministro degli Affari Esteri Tommaso Tittoni, nella seduta del 13 febbraio 1908'. Rivista Coloniale 4 (1): 111-34.

Tomasella, G. 2017. Esporre l'Italia coloniale. Interpretazioni dell'alterità. Padua: Il Poligrafo.

Toschi, A. 1941. 'La milizia forestale'. Annali dell'Africa Italiana 4 (2): 602.

Troilo, S. 2012. 'Pratiche coloniali. La tutela tra musealizzazione e monumentalizzazione nella Rodi "italiana" (1912-1926)'. Passato e Presente 87: 80-104.

Zaccaria, M. 2002. 'L'Eritrea in mostra. Ferdinando Martini e le esposizioni coloniali, 1903-1906'. Africa 57 (4): 512-45.

Zavattari, E. 1934. 'Relazione preliminare sulle ricerche di biologia sahariana compiute nel Fezzan'. Bollettino della $R$. Società geografica italiana 71: 318-24.

Zavattaro, M. 2014. 'Collezioni Somalia'. In Il Museo di Storia Naturale dell'Università degli Studi di Firenze. Vol. 5: Le collezioni antropologiche ed etnologiche, edited by J. Moggi Cecchi and R. Stanyon, 68-71. Florence: Florence University Press.

\section{Italian summary}

Se il modello fascista di esibire e "musealizzare" il potere affonda indubbiamente le sue radici nelle esposizioni liberali della seconda metà dell'Ottocento e nelle prime esposizioni dedicate al Risorgimento, è 
innegabile che le iniziative museali del fascismo furono numerose, innovative e varie, molte delle quali ancora non sufficientemente indagate. In particolare, gli interventi museali del regime in colonia restano ancora in gran parte inesplorati. Lo scopo di questo lavoro è quello di sottolineare il sorprendente network di esibizioni temporanee e musei creati dal fascismo nelle colonie, coinvolgendo figure di spicco del regime e della cultura dell'epoca, e di evidenziare come scienza, cultura e nation-building (della colonia e della madrepatria) si intreccino nel progetto di museologia coloniale del regime. 